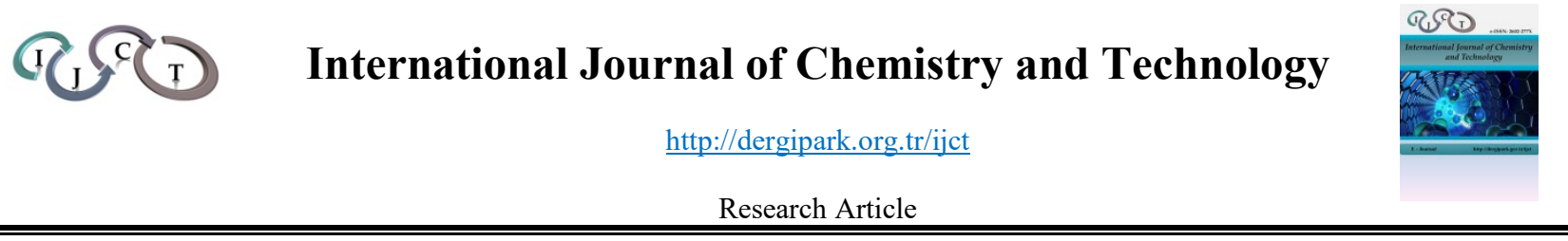

\title{
The anticancer activity of chalcone compounds against human prostate carcinoma cell and human colon colorectal adenocarcinoma
}

\author{
DBedriye Seda KURŞUN AKTAR ${ }^{1}$, (DAyşe ŞAHIN YAĞLIOĞLU ${ }^{2, *}$, (DEmine Elçin ORUÇ-EMRE³ \\ ${ }^{1}$ Department of Property Protection and Security, Yapraklı Vocational School, Çankırı Karatekin University, 18000, Çankırl, Turkey \\ ${ }^{2}$ Technical Sciences Vocational School, Department of Chemistry and Chemical Process Technology, Amasya University, 05200, \\ Amasya, Turkey \\ ${ }^{3}$ Department of Chemistry, Faculty of Arts and Sciences, Gaziantep University,27000, Gaziantep, Turkey
}

Received: 4 April 2021; Revised: 01 June 2021; Accepted: 01 June 2021

*Corresponding author e-mail:aysesahin1@gmail.com

Citation: Kurşun, Atar, B. S.; Şahin, Yağlığlu, A.; Oruç- Emre, E. E. Int. J. Chem. Technol. 2021, 5 (1), $52-58$.

\section{ABSTRACT}

Cancer is the second most common cause of death in our country and also worldwide. In the cancer treatment are used many methods such as surgery, chemotherapy, radiotherapy and hormone therapy. Despite these methods, a decrease is not observed in cancer cases and in the mortality. In addition, cancer drugs cause serious side effects. Therefore, there is a need for new anticancer drugs. Chalcones have broad anticancer activity against various cancer cells. In this study, the anticancer activities of the chalcone compounds were investigated against PC3 (Human Prostate Carcinoma Cell) and HT29 (Human colon colorectal adenocarcinoma) cell lines. The anticancer activity tests were performed using the BrdU ELISA method. 5-Fluorouracil (5-FU) was used as the positive control. Compound 1-7 (except Compound 3) were determined having higher anticancer activity than 5-FU against PC3 cancer cells. IC 50 values of the compounds 1-7 against $\mathrm{PC} 3$ cancer cells were $2.53 \pm 0.02 \mu \mathrm{M} ; 4.40 \pm 0.03 \mu \mathrm{M} ; 5.86 \pm 0.02 \mu \mathrm{M} ; 4.36 \pm 0.03 \mu \mathrm{M}$; $1.76 \pm 0.02 \mu \mathrm{M} ; 1.78 \pm 0.03 \mu \mathrm{M} ; 2.31 \pm 0.03 \mu \mathrm{M}$, respectively.

Keywords: HT29, PC3, Chalcone, 5-Fluorouracil, Fluor atom, anticancer activity.
Kalkon bileşiklerinin insan prostat karsinom hücresi ve kolon kolorektal adenokarsinomuna karşı antikanser aktivitesi

ÖZ

Kanser, ülkemizde ve dünya çapında en yaygın ikinci ölüm nedenidir. Kanser tedavisinde ameliyat, kemoterapi, radyoterapi ve hormon tedavisi gibi birçok yöntem kullanılmaktadır. Bu yöntemlere rağmen kanser vakalarında ve ölümlerde azalma gözlenmemektedir. Ayrıca kanser ilaçları ciddi yan etkilere neden olur. $\mathrm{Bu}$ nedenle yeni antikanser ilaçlara ihtiyaç vardır. Kalkonlar, çeşitli kanser hücrelerine karşı geniş bir antikanser aktivitesine sahiptir. Bu çalışmada kalkon türevlerinin antikanser aktiviteleri PC3 (insan prostat karsinom hücresi) ve HT29 (İnsan kolon kolorektal adenokarsinom) hücre hatlarına karşı araştırılmıştır. Antikanser aktivite testleri BrdU ELISA yöntemi kullanılarak yapıldı. Pozitif kontrol olarak 5-Florourasil (5-FU) kullanıldı. Bileșik 17 (Bileşik 3 hariç), PC3 kanser hücrelerine karş1 5-FU'dan daha yüksek antikanser aktiviteye sahip olduğu belirlendi. Bileşik 17'nin PC3 kanser hücrelerine karş1 $\mathrm{IC}_{50}$ değerleri sırasıyla, $2.53 \pm 0.02 \mu \mathrm{M} ; 4.40 \pm 0.03 \mu \mathrm{M} ; 5.86 \pm 0.02 \mu \mathrm{M} ; 4.36 \pm 0.03 \mu \mathrm{M}$; $1.76 \pm 0.02 \mu \mathrm{M} ; 1.78 \pm 0.03 \mu \mathrm{M} ; 2.31 \pm 0.03 \mu \mathrm{M}$ 'd 1 .

Anahtar Kelimeler: HT29, PC3, Kalkon, 5-Flurourasil, Flor atomu, Antikanser aktivite.

in the world gets cancer during their lifetime. 1 in every 8 men and 1 in every 11 women die of cancer. ${ }^{1}$ The most common cancers seen in men are lung, prostate and colorectal cancers. In women, breast, lung, colorectal and
Cancer is the second most common cause of death in our country and also worldwide. One out of every 5 people 
cervical cancers are seen the most common. ${ }^{1}$ According to current estimates, 19.3 million new cases were diagnosed in 2020, and the cancer burden increased to 19.3 million new cases and 10.0 million deaths in $2020{ }^{1}$ The top 5 most common types of cancer in our country in 2020 were lung cancer $(17.6 \%)$, breast cancer $(10.3 \%)$, colorectal (colon) cancer $(9.1 \%)$, prostate cancer $(8.3 \%)$ and thyroid cancer $(5.9 \%)$. These 5 types of cancer accounted for more than $50 \%$ of all cancers. ${ }^{2}$

Worldwide, 14 million new cases of prostate cancer diagnosed and 375,304 prostate cancer (PCA) deaths occurred in 2020. The second most common cancer in men is PCA in 2020. ${ }^{1}$ This type of cancer ranks fifth among cancer-related deaths. PCA is the most common cancer among men in more than half of the countries of the world. (105 out of 185); particularly in America, Northern and Western Europe, Australia/New Zealand and a large part of Sub-Saharan Africa. ${ }^{3}$ The natural course of this disease is quite heterogeneous and is still poorly understood. As a result of autopsy studies, prostate cancer is diagnosed in about one out of every three men over the age of $50.80 \%$ of these tumours are $0.5 \mathrm{~cm}$ in size and low grade. In addition, the majority are considered to be clinically insignificant. ${ }^{4}$ Increasing incidences and mortality due to PCA and the failure of traditional chemo and radiotherapy of advanced invasive PCA show that essentially new approaches are needed to control this malignancy. 5,6

In 2020, there were more than 1.9 million new colorectal cancer diagnoses and 935,000 deaths. This situation shows that approximately one out of every 10 cases of cancer results in death. Generally, colorectal cancer ranks third in terms of the incidence and second in mortality. ${ }^{3}$ If diagnosed and treated at the early stages, colorectal cancer is one of the most treatable types of cancer. ${ }^{7}$ Various systemic treatments such as surgery, chemotherapy, radiotherapy and hormone therapy are used for cancer treatment. ${ }^{8,9}$ Despite these treatment methods, a decrease is not observed neither in the number of patients with this disease nor in the mortality rate. ${ }^{9}$ In addition, cancer drugs cause toxicity in normal cells and tissues, causing serious side effects such as vomiting, nausea, hair loss, and resistance development., ${ }^{3,10-11}$ Therefore, there is a need for anticancer drugs that are reliable, powerful, non-toxic, economical and environment friendly. In a study we conducted in 2017 , we synthesized the chalcone derivatives included in the present article and investigated the anticancer activities against $\mathrm{HeLa}$ and C6 cancer cells. As a result of our research, it was determined that these molecules showed higher anticancer effects than 5-Fluorouracil and Cisplatin, which were used as positive controls. ${ }^{12}$ Thus, we examined the anticancer activities of these chalcone derivatives against PC3 (Human Prostate Carcinoma Cell) and HT29 (Homo sapiens colon colorectal adenocarcinoma) cell lines in the manuscript. The chalcone compounds in this study contain morpholine rings in the structure of cancer drugs such as Alectinib, Gefitinib and Canertinib (Figure 1). In addition, these chalcone compounds contain fluorinated organic structures such as 5-Fluorouracil, Floxuridin and Flutamid, which are also used in cancer treatment (Figure 1)

Chalcones consist of aryl rings linking to an $\alpha, \beta$ unsaturated ketone group. The easy synthesis of chalcones from various benzaldehyde and acetophenones enables them to be used in drug synthesis. Chalcones possess a number of biological effects such as antimalaria, antibacterial, antiinflammatory and anticancer. $^{13}$

Fluorine atom provides two kinds of biological and chemical effects to the molecule. The organofluorine compounds have some features as shown in Table $1 .{ }^{14}$

Table 1. The chemical and biological effects of organofluorine compounds.

\begin{tabular}{|l|l|}
\hline Chemical effect & Biological effect \\
\hline Small size & Electronegativity of neighboring groups \\
\hline Lipophilic & Strong C-F bonds resistant to metabolic processes \\
\hline High electronegativity & Increases lipid solubility (bioavailability) \\
\hline Low reactivity & $\begin{array}{l}\text { Synthesis of isosteric analogues of drugs } \\
\text { Useful for studying biochemical processes }\end{array}$ \\
\hline
\end{tabular}


<smiles>CCc1cc2c(cc1N1CCC(N3CCOCC3)CC1)C(C)(C)c1[nH]c3cc(C#N)ccc3c1C2=O</smiles>

Alectinib<smiles>C=CC(=O)Nc1cc2c(Nc3ccc(F)c(Cl)c3)ncnc2cc1OCCN1CCOCC1</smiles>

Canertinib<smiles>COc1cc2ncnc(Nc3ccc(F)c(Cl)c3)c2cc1OCCCN1CCOCC1</smiles><smiles>O=c1[nH]cc(F)c(=O)[nH]1</smiles>

5-Fluorouracil<smiles>O=c1[nH]c(=O)n(C2C[C@H](O)[C@@H](CO)O2)cc1F</smiles>

Floxuridin<smiles>CC(C)C(=O)Nc1ccc([N+](=O)[O-])c(C(F)(F)F)c1</smiles>

Flutamid

Figure 1. The anticancer drugs

\section{MATERIALS AND METHODS}

\subsection{Preparation of compounds solution}

The compounds and 5-Fluorouracil (5-FU) were dissolved in dimethyl sulfoxide (DMSO). The solution was diluted with Dulbecco's Modified Eagle Medium (DMEM). DMSO amount was below $0.1 \%$ in the solutions. 5-FU was used as the positive control.

\subsection{Anticancer activity method}

The tests were carried out on PC3 and HT29. The cells were purchased from the American Type Culture Collection (ATCC) with codes of HT-29 (ATCC $\AA$ HTB38 $^{\mathrm{TM}}$ ) and PC-3 (ATCC $\AA$ CRL-1435 ${ }^{\mathrm{TM}}$ ). The cells were cultured in DMEM $(10 \%$ of fetal bovine serum (FBS)- $2 \%$ of penicillin-streptomycin). DMEM was refreshed once in three days at $37{ }^{\circ} \mathrm{C}$ and $5 \% \mathrm{CO}_{2}$ in an incubator. 5-FU was used as the standard drug. The microplate wells were pipetted with 30.000 cells, then incubated for 30 minutes in $\mathrm{CO}_{2}$ incubator. At the end of $30 \mathrm{~h}$, the wells were added to the sample solutions on four concentrations. Then, the microplates were incubated overnight in same conditions. The tests were carried out in accordance with the BrdU ELISA kit protocol. Measurements were measured in ELISA reader at 450 $\mathrm{nm}$. The activity was calculated as follows:

[1- $\left(\mathrm{A}_{\text {treatments }} / \mathrm{A}_{\text {vehicle control }}\right] \times 100$.

$\mathrm{IC}_{50}$ was calculated by ED50 plus v1.0, and the results were specified as means $\pm \mathrm{SD}$ of six values. The statistical analysis was made with SPSS $13.5(\mathrm{p}<0.01)$.

\section{RESULTS AND DISCUSSION}

Anticancer effects of all the samples and 5-fluorouracil (5-FU) were determined against HT29 cells at 100, 50, 25 and $5 \mu \mathrm{M}$. The $\mathrm{IC}_{50}$ values of all the samples were given at Table 2. The anticancer activities of all the samples were observed as showing dose-dependent increase in activity against HT29 cells (Figure 2). Compound 6 against HT29 cells were determined as having an effect fairly close to 5-FU. However, other compounds have better anticancer activities than 5-FU at high concentrations. The potency of inhibitions (at 100 $\mu \mathrm{M}$ ) against HT29 cells were: compound 7 compound 3 $\sim$ compound 6>5-FU $>$ compound $\mathbf{2}>$ compound 4 compound $\mathbf{1}>$ compound $4>$ compound $\mathbf{5}$. 
Table 2. The $\mathrm{IC}_{50}$ values $(\mu \mathrm{M})$ of compounds 1-7 against HT29 and PC3 cancer cells

\begin{tabular}{|c|c|c|c|}
\hline \multirow[t]{2}{*}{ No } & \multirow[t]{2}{*}{ Compound structure and name } & \multicolumn{2}{|c|}{$\mathrm{IC}_{50}$} \\
\hline & & HT29 & PC3 \\
\hline 1 & $\begin{array}{c}\text { (E)-3-(2-fluoro-3-(trifluoromethyl)phenyl)-1-(4- } \\
\text { morpholinophenyl) prop-2-en-1-one }\end{array}$ & $6.26 \pm 0.03$ & $2.53 \pm 0.02$ \\
\hline 2 & (E)-3-(2-fluoro-4-(trifluoromethyl)phenyl)-1-(4- & $5.50 \pm 0.02$ & $4.40 \pm 0.03$ \\
\hline 3 & $\begin{array}{l}\text { (E)-3-(2-fluoro-6-(trifluoromethyl)phenyl)-1-(4- } \\
\text { morpholinophenyl) prop-2-en-1-one }\end{array}$ & $7.03 \pm 0.02$ & $5.86 \pm 0.02$ \\
\hline 4 & $\begin{array}{c}\text { (E)-3-(4-fluoro-3-(trifluoromethyl)phenyl)-1-(4- } \\
\text { morpholinophenyl) prop-2-en-1-one }\end{array}$ & $7.89 \pm 0.05$ & $4.36 \pm 0.03$ \\
\hline 5 & 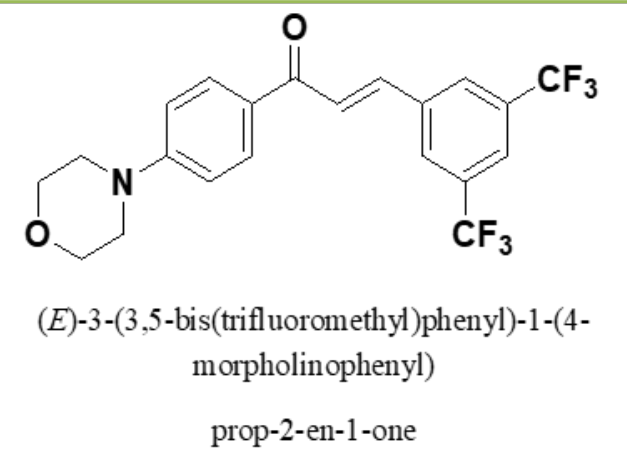 & $3.38 \pm 0.01$ & $1.76 \pm 0.02$ \\
\hline
\end{tabular}


Table 2. Continued

\begin{tabular}{|c|c|c|c|}
\hline 6 & (trifluoromethoxy)phenyl) prop-2-en-1-one & $2.11 \pm 0.01$ & $1.78 \pm 0.03$ \\
\hline 7 & 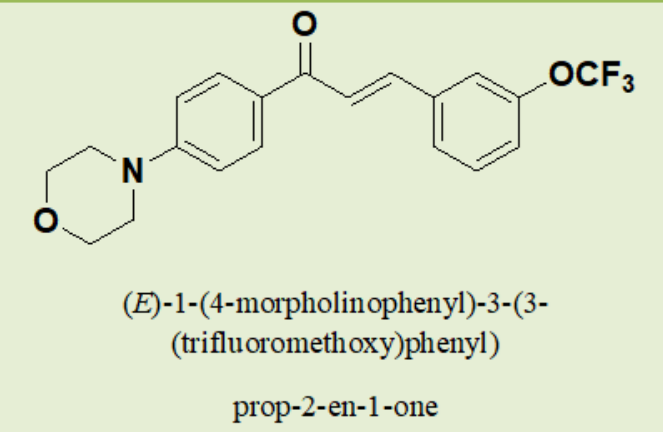 & $5.52 \pm 0.02$ & $2.31 \pm 0.03$ \\
\hline 5-FU & $\underbrace{F}_{\prod_{0}^{N H}}$ & $2.04 \pm 0.01$ & $5.69 \pm 0.02$ \\
\hline
\end{tabular}

against HT29 cell line

$\square 1 \square 2 \square 3 \square 4 \square 5 \square 6 \square 7 \square 5-F U$

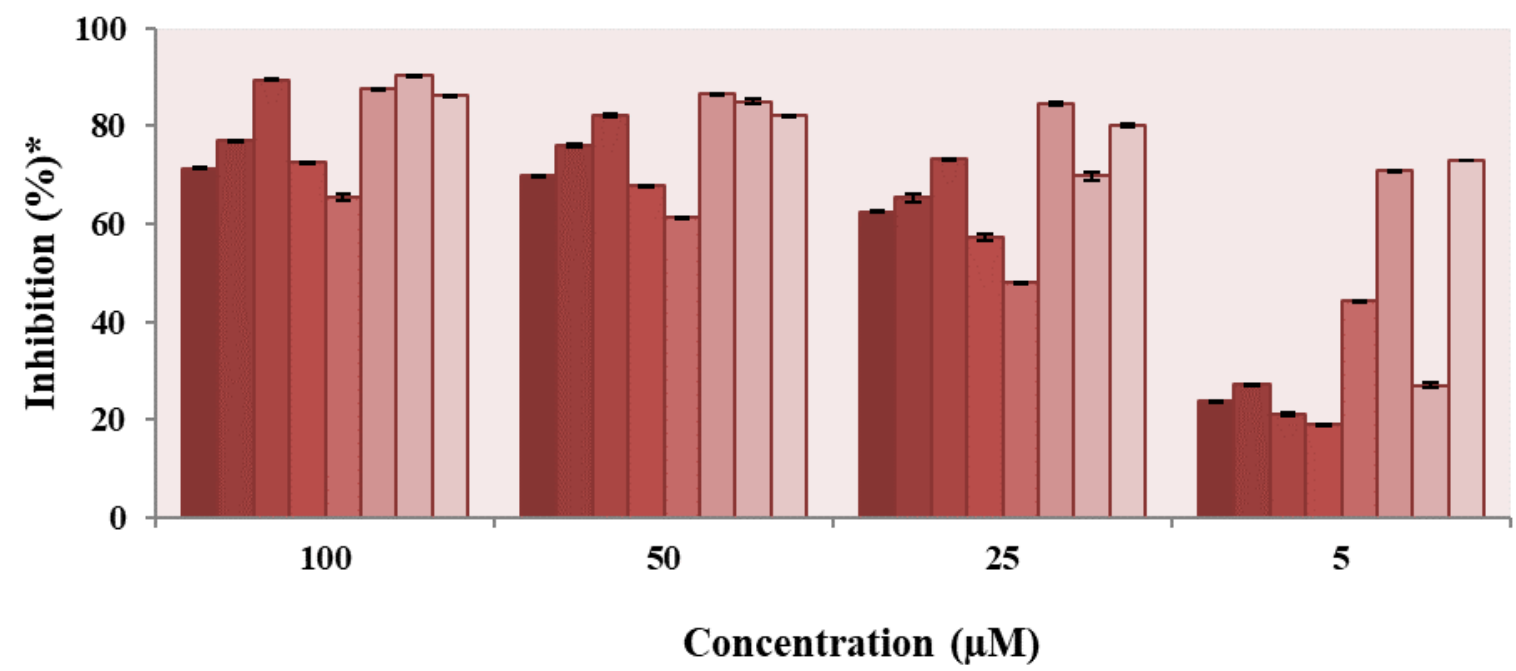

Figure 2. The anticancer activities of all the samples and 5-FU against HT29 cells. * tests were carried out as two experiments with triplicate $(n=6 ; p<0.01)$.

Anticancer activities of all the samples and 5-FU were determined against PC3 cells at four concentrations (Figure 3 ). The $\mathrm{IC}_{50}$ values of compounds 1-7 are given at Table 2. The anticancer activities of compounds 1-7 were observed as showing dose-dependent increase in activity against PC3 cells (Figure 3). All of the compounds (except Compound 3) were determined to have higher anticancer activities compared with 5-FU which was used as the standard compound against PC3 cells. Compound $\mathbf{3}$ against HT29 cells were determined 
to have fairly close to the 5-FU. The potency of inhibitions (at $100 \mu \mathrm{M}$ ) against PC3 cells were: compound $\mathbf{5} \sim$ compound $\mathbf{6}>$ compound $\mathbf{7}>$ compound $\mathbf{1}>$ compound $\mathbf{4} \sim$ compound $\mathbf{2}>5$-FU $\sim$ compound $\mathbf{3}$.

Compound 5 has the highest anticancer activity against PC3 cells $\left(\mathrm{IC}_{50}\right.$ : $\left.1.76 \pm 0.02 \mu \mathrm{M}\right)$. Compound 5 contains two $\mathrm{CF}_{3}$ groups. It contains the highest number of $\mathrm{CF}_{3}$ groups compared to the groups found in other molecules.
The fluorine atom has slightly more lipophilic property than hydrogen. However, trifluoromethyl $\left(\mathrm{CF}_{3}\right)$ is much more lipophilic than methyl or chlorine. This property often has the most important role in improving pharmacological activity. ${ }^{15}$ This supports the high activity of our compound $\mathbf{5}$.

against $P C 3$ cell line

$\square 1 \square 2 \square 3 \square 4 \square 5 \square 6 \square 7 \square 5-F U$

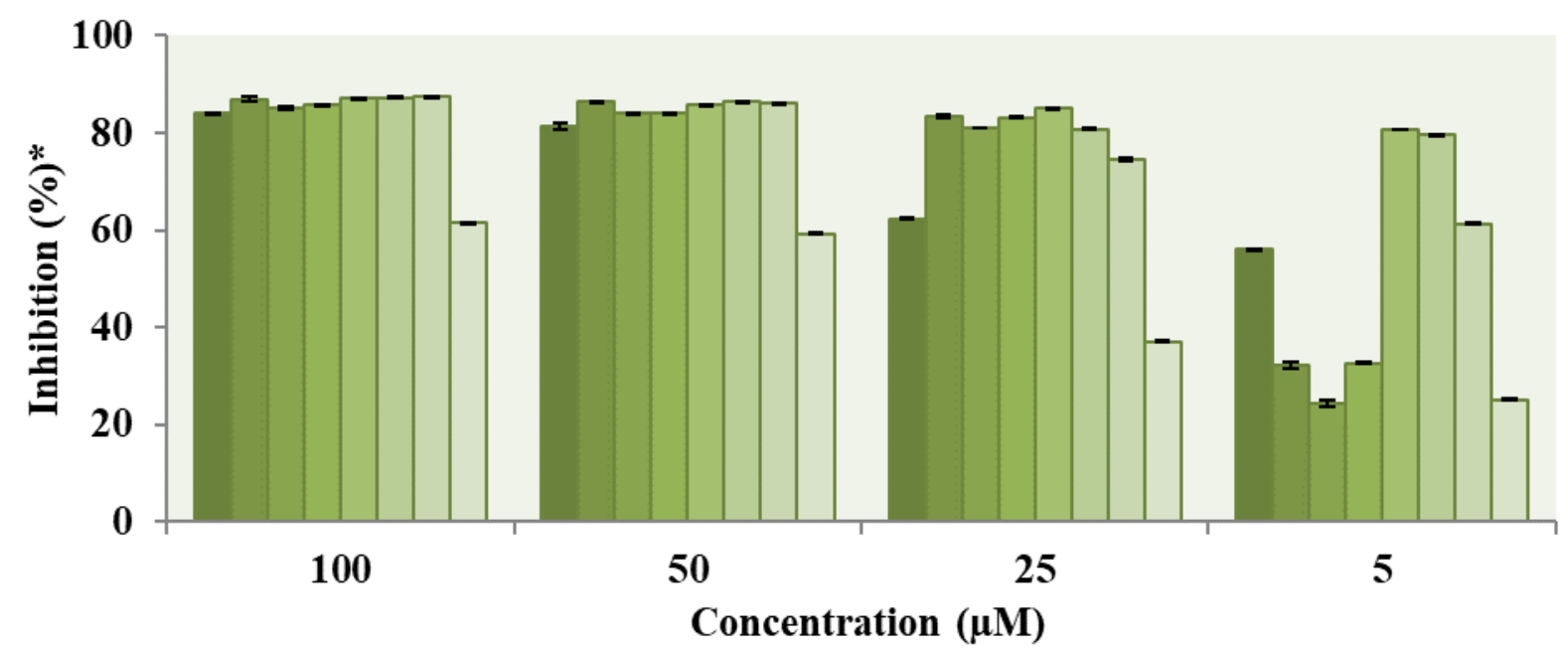

Figure 3. The anticancer activities of all the samples and 5-FU against PC3 cells. * tests were carried out as two experiments with triplicate $(n=6 ; p<0.01)$.

The fluor and trifluoromethyl (electron-withdrawing groups) groups attached to the phenyl ring of chalcone in compound $\mathbf{1}$ are in position at 2-fluor and 3trifluoromethyl. The same groups are in position at 2fluor and 4- trifluoromethyl in compound 2. $\mathrm{IC}_{50}$ values for compound $\mathbf{1}$ and compound $\mathbf{2}$ against PC3 cells are $2.53 \pm 0.02 \mu \mathrm{M}$ and $4.40 \pm 0.03$, respectively. It was seen that the activity against PC3 cancer cells in the 2-3 position was higher than the one in the $2-4$ position. F and $\mathrm{CF}_{3}$ groups are in position at 2-fluor and 6trifluoromethyl in compound $\mathbf{3}$, and $\mathrm{IC}_{50}$ value of the compound is determined as $5.86 \pm 0.02 \mu \mathrm{M}$. When the fluorine and trifluoromethyl groups moved away from each other, a decrease in activity, such as compound $\mathbf{3}$, was detected. The anticancer activities of Compound 1-7 against PC3 were better than the ones against HT29.

The binding of a fluorine atom to a bioactive molecule causes minimal steric changes. Thus, it can facilitate the biomolecule's biological effects such as interaction with enzyme active sites, receptor recognition sites, and biological effects such as transport mechanisms. However, the addition of fluorine significantly changes the physicochemical properties of the bioactive molecule due to its great electronegativity. Therefore, these modified processes can affect biological activity. ${ }^{16}$ Bioisosteric derivatives of fluorine instead of the hydrogen atom are to further increase the activity of biologically active molecules. ${ }^{14,17-19}$ Due to the chemical and biological properties of organofluorine compounds (Table 1), fluorine has become very important for predictions of new drugs and their development. ${ }^{15,20-22}$ Because of this, it affects the number of drugs that contain fluorine in the market today. ${ }^{23}$ As in our study, fluorinated chalcone derivatives show anticancer activity. ${ }^{13,17,24,25}$

\section{CONCLUSIONS}

Fluorine has chemical and biological properties. Thus it becomes very important for the planning and development of new drugs. Organofluorine structures affect the number of drugs that contain fluorine in the market today. In the study, fluorinated chalcone derivatives especially show higher anticancer activity against PC3 cancer cells compared to 5-FU.

\section{ACKNOWLEDGEMENTS}

This study was supported by the Gaziantep University Scientific Research Projects Governing Unit (BAPYB) (Project no: FEF.14.01), Turkey. The authors are also grateful to Esin Ekmekci for the grammatical revision of the manuscript. 


\section{Conflict of interests}

I declare that there is no a conflict of interest with any person, institute, company, etc.

\section{REFERENCES}

1. WHO, 2020. https://www.drozdogan.com/dunyakanser-istatistikleri-2020-her-5-kisiden-biri-kanserlekarsilasiyor/ (accessed May 26, 2021).

2. TUIK (Turkey Statistical Institute), 2020. https://www.drozdogan.com/turkiye-kanseristatistikleri-2020/ (accessed May 27, 2021).

3. Sung, H.; Ferlay, J.; Siegel, R.L.; Laversanne, M.; Soerjomataram, I.; Jemal, A.; Bray, F. CA Cancer J. Clin. 2021, 71, 209-24.

4. Yatani, R.; Chigusa, I.; Akazaki, K.; Stemmermann, G.N.; Welsh, R.A.; Correa, P. Int. J. Cancer. 1982, 29, 611-616.

5. Koivisto, P.; Kolmer, M.; Visakorpi, T.; Kallioniemi, OP. Am. J. Pathol. 1998, 152, 1-9.

6. Feldman, B.J.; Feldman, D. Nat. Rev. Cancer 2001, 1, 34-45.

7. Madhavi, S.; Sreenivasulu, R.;Yazala, J.P. Saudi Pharm. J. 2017, 25, 275-279.

8. Damyanov, C.; Maslev, I.; Pavlov, V.; Avramov, L. Ann. Complement. Altern. Med. 2018,1,1002.

9. Singh, S.P.; Mishra, A.; Shyanti, R.K.; Singh, R.P.; Acharya, A. Biol. Trace. Elem. Res. 2021, 199, 13161331.

10. Szakacs, G.; Paterson, J.K.; Ludwig, J. A.; BoothGenthe, C.; Gottesman, M.M. Nat. Rev. Drug. Discov. 2006, 5, 219-234.

11. Karmous, I.; Pandey, A.; Haj, K.B.; Chaoui, A. Biol. Trace. Elem. Res. 2020,196, 330-342.

12. Kursun Aktar, B.S.; Oruç-Emre, E.E.; Demirtas, I.; Sahin Yaglioglu, A.; Guler, C.; Adem, S.; Karaküçük Iyidogan, A. J. Mol. Struct. 2017, 1149, 632-639.
13. Lawrence, N.J.; Patterson, R.P.; Ooi, L.; Cook, D.; Ducki, S. Bioorg. Med. Chem. Lett. 2006, 16(22), 58445848.

14. Burmaoglu, S.; Algul, O.; Anıl, D.A.; Gobek, A.; Duran, G.G.; Ersan, R.H.; Duran, N. Bioorg. Med. Chem. Lett. 2016, 26(13), 3172-3176.

15. Filler, R.; Saha, R. Future Med. Chem. 2009, 1(5), 777-791.

16. Ojima, I. Chem. Bio. Chem. 2004, 5, 628-635.

17. Padhye, S.; Ahmad, A.; Oswa, N.; Dandawate, P.; Rub, R.A.; Deshpande, J.; Swamy, K.V.; Sarkar, F.H. Bioorg. Med. Chem. Lett. 2010, 20(19), 5818-5821.

18. Kurun, B.S.; Oruç.-Emre, E.E.; Karaküçük-İyidoğan, A.; Sahin Yaglioglu, A.; Tekin, S.; Demirtaş İ. Turkish Patent Institue PATENT No: 2011/05601, 2011.

19. Sun, LP.; Gao, L.X.; Ma, W.P.; Nan, F.J.; Li, J.; Piao, H.R. Chem. Biol. Drug. Des. 2001, 80(4), 584-90.

20. Ojima, I. J. Org. Chem. 2013,78, 6358-6383.

21. Hagmann, W.K. J. Med. Chem. 2008, 51, 4359-4369.

22. Isanbor, C.; O'Hagan, D. J. Fluorine Chem. 2006, 127, 303-319.

23. Abad, A.; Agullo, C.; Cunat, A.C.; GonzalezColoma, A.; Pardo, D. Eur. J. Org. Chem. 2010, 11, 2182-2198.

24. Nakamura, C.; Kawasaki, N.; Miyataka, H.; Jayachandran, E.; Kim, I. H.; Kirk, K. L. Bioorg. Med. Chem. 2002, 10(3), 699-706.

25. Lim, Y.H.; Oo, C.W.; Koh, R.Y.; Voon, G.L.; Yew, M.Y.; Yam, M.F.; Loh, Y.C. Drug. Dev. Res. 2020, 81, 994-1003. 